\title{
Thinking and Practice in Research-oriented Instruction for Undergraduate Major of the Electrical Engineering Field
}

\author{
GONG Maokang \\ Guangling College \\ Yangzhou University \\ Yangzhou, China \\ mkgong@yzu.edu.cn
}

\author{
ZHOU Lei \\ College of Information Engineering \\ Yangzhou University \\ Yangzhou, China \\ Tomcat800607@126.com
}

\begin{abstract}
This paper discusses the purpose, methods and characteristics of research-oriented instruction in the popularization of undergraduate education condition. Based on the teaching practice of the undergraduate course of electronic information, this paper introduces the experiments and effects of developing the research-oriented instruction according to local conditions and promoting the students' studying attitude using research. The results prove that it is the key that inspiring the interest and scientific attitude of students during the teaching of Professional course.
\end{abstract}

Keywords - research-based instruction; undergraduate teaching; electrical engineering field; academic competition

\section{INTRODUCTION}

The research-oriented instruction has been proposed for nearly a decade in colleges and universities, and has been positively responded to by teachers and teaching management departments. A large number of research-oriented instruction methods with specific specialties have been applied in teaching, which has promoted the improvement of teaching quality. Generally speaking, "research-oriented instruction" has broad and narrow sense of two kinds of understanding. In broad sense understanding, it refers to the promotion of students to learning by the attitude of explore; While in narrow sense, it refers to the students select and determine the topic of research from the natural, social and life by themselves, and take the initiative to acquire knowledge, apply knowledge, problem-solving learning activities under the guidance of teachers [2].

The author engaged in the electronic and information department undergraduate teaching nearly 30 years, teaches the "signal and linear system analysis", "digital signal processing", "single-chip processor principle and application", "DSP processor principle and application", "electronic system design "And other professional courses in all aspects of the teaching tasks, guides graduation design and organizes students to participate in the national college students electronic design competition. In recent years, I have been concerned about the idea of "research-oriented instruction ", and tried to applied it into the processes of professional courses teaching. But there's still many problems leave. For example, research teaching is a concept or a carrier? What is the purpose of research-oriented instruction in the popularization of undergraduate education? Except to the specific research-oriented instruction, how to carry out research-oriented instruction in the electronic information undergraduate professional teaching practice? Therefore, some superficial views are listed as below to discuss.

\section{THE PURPOSE OF RESEARCH-ORIENTED INSTRUCTION SHOULD BE "GRANTING PEOPLE WITH FISHING"}

The education methods have been proposed since the education arises. Different educational stages should have different educational ideas; different talent training objectives should have different educational ideas. In the popularization of undergraduate education, the main problem encountered in research-oriented instruction is that the research methods of specific fields are difficult to be fully expounded. [3] In the subject of higher degree of discipline, such as electronic information specialty, research-oriented instruction requires a certain degree of knowledge accumulation; otherwise it is difficult to achieve a certain height. Therefore, combined with the actual undergraduate education and teaching practice, the specific research teaching methods only are carried out in the conditions allowed to, while in other circumstance should be more generalized "research-oriented instruction", that is, stressed that college students should be a research attitude Learning, research-oriented instruction should be the purpose of "grant people to fishing."

The author strongly suggested that, in the arrangement of the professional teaching plan, the teaching schedule of the professional basic course is as early as possible, so as to free the students to carry out the study time interval, which is benefit to carry out generalized research-oriented instruction, also benefit to carry out narrow research-oriented instruction which take special subject as key point.

\section{THE METHOD OF RESEARCH-ORIENTED INSTRUCTION SHOULD BE "INDIVIDUALIZED"}

No matter what type of course study, are bound to encounter the problem of methodology. Learning from a research attitude is one of the best ways to learn. Combined with different professional, combined with different professional courses learning stage, combined with different 
teaching stage, there're different research learning methods. The teachers who advocate the research-oriented instruction should introduce the research-oriented instruction method to the students in combination with the actual teaching process and carry out the research-oriented instruction according to the individual teaching. The basic course of electronic information specialty has the characteristics of high threshold, strict mathematical requirements and complicated experimental techniques. It requires students having precise logical thinking ability and mastering many mathematical tools to get conclusions. Also students need to have fertile imagination, which can be linked complex conclusions and specific physical meaning to the experimental phenomena.

The author in the decades of process of teaching, pay attention to take a variety of ways to guide students to learning in a study attitude combined with teaching practice. In this case, the experience can be summarized as follows:

\section{A. To classify and summarize in class}

Summary is the method of studying the knowledge system, and master the knowledge system is the main purpose of course teaching, but also the basis of the study. The author undertakes the "signal and linear system analysis" course, mainly on the basic analysis of electronic communication systems. In this course the summary of the composition of the signal composition, the summary of the system time domain analysis method which adapt to transformation, the summary of the system zero pole position, the summary of system function convergence domain and the summary of system characteristics are chosen as the main example, using the list of characteristics to guide students to fill in the summative form. These lists and forms can guide students to learn to sum up, with particular attention to the question mark options. Students who matriculated by the 211 and 985 universities of graduate school generally reflected that the "Signal and Linear Systems Analysis" course help them to get an ideal result of their total score.

\section{B. To promote the comparative research in guiding experiments}

There is no identify without comparison, the students only can select the accurate results after learning to identify. To achieve this goal, we first need to adjust the existing experimental content. Therefore, we have redesigned the "digital signal processing" experimental outline, the specific arrangements shown in Table I.

TABLE I. "DIGITAL SIGNAL PROCESSING" EXPERIMENTAL OUTLINE

\begin{tabular}{|l|l|c|}
\hline \multicolumn{1}{|c|}{ Name } & \multicolumn{1}{|c|}{ Purpose } & Type \\
\hline $\begin{array}{l}\text { Signal sampling } \\
\text { and reconstruction }\end{array}$ & $\begin{array}{l}\text { Understand the general structure of } \\
\text { digital signal processing system, } \\
\text { through the simulation and } \\
\text { comprehensive experimental box to } \\
\text { master the Nyquist sampling theorem. }\end{array}$ & Verification \\
\hline $\begin{array}{l}\text { Discrete Fourier } \\
\text { Transform and Its }\end{array}$ & $\begin{array}{l}\text { Through the simulation and synthesis } \\
\text { of experimental box to deepen the } \\
\text { Fast Algorithm } \\
\text { of fast Fourier transform (FFT), } \\
\text { observe the relationship between FFT } \\
\text { points and resolution. }\end{array}$ & Design \\
\hline
\end{tabular}

\begin{tabular}{|l|l|l|}
\hline \multicolumn{4}{|c|}{ Cont. to TABLE I } \\
\hline \multirow{2}{*}{$\begin{array}{l}\text { Design Method of } \\
\text { IIR Filter }\end{array}$} & $\begin{array}{l}\text { Through the simulation and synthesis } \\
\text { of experimental box to understand the } \\
\text { basic principles of IIR filter } \\
\text { understanding, learning to write IIR } \\
\text { filter MATLAB simulation program. }\end{array}$ & Design \\
\hline Design Method of & $\begin{array}{l}\text { Through the simulation and } \\
\text { comprehensive experimental box to } \\
\text { deepen the understanding of the basic } \\
\text { principles of FIR filter, learning using } \\
\text { window function method, frequency } \\
\text { sampling method designed FIR filter. }\end{array}$ & Design \\
\hline
\end{tabular}

In addition to adjusting the experimental outline, in the course of the experiment for different cases of classification guidance is an important way to compare the experimental study. When instructing the experiment of filter design in "digital signal processing" and "DSP processor principle and application" course, the author requires the students to design the FIR and IIR filters with the same amplitude and frequency index, and add the same square wave signal, focus on and compare the difference of the phase frequency characteristics of the output signal and the order of these two filters, to deepen the understanding of the digital filter design. When asking the students to do experiments and complete experimental reports, the author requires not paying attention to everything concerned, but the comparison. It will certainly deepen the understanding of the theory by comparison. According to the reflect by the students who take my class, these teaching methods inspire them to understand and master the knowledge of this course more deeply.

\section{To promote method research during solving problems}

The unfamiliar topic is just a new research topic for the student. When I am talking about examples and exercises, pay attention to emphasize the limitations of the method of solving these problems introduced by the prerequisite course, the diversity of the problem-solving methods in this course, and the possibility of solving methods in the follow-up course, to guide the students focus on the solving method of the same problem. For example, when teaching the periodic signal spectrum analysis of the "Signal and Linear System Analysis" course, I explain to the students that the phonetic analysis in the course of the "Fundamentals of Circuits" is only suitable for the single frequency sinusoidal signal, while Fourier series and Fourier transform analysis in this course, and FFT analysis method in the "digital signal processing", are the better tools to solving these problems. As for the specific problem-solving process, I require students to learn and digest by themselves. In the revision of "single-chip processor principle and application" subject of programming type, the requirements to students are following the rules of program debugging and writing down the process of program debugging, the purpose of which is leading students to master the basic method of programming and debugging. In addition, in the "electronic system design" course, the author also combine electronic courses with the actual training of practical training programs, to train students to specific electronic design problems to solve and achieve capacity. The specific training content is shown in Table II. 
TABLE II. ELECTRONIC SYSTEM DESIGN" TRAINING CONTENTS

\begin{tabular}{|l|l|l|}
\hline \multicolumn{1}{|c|}{ Name } & \multicolumn{1}{c|}{ Purpose } & \multicolumn{1}{c|}{ Project } \\
\hline $\begin{array}{l}\text { Single chip } \\
\text { system design }\end{array}$ & $\begin{array}{l}\text { Design of Control System } \\
\text { Based on Single Chip } \\
\text { Microcomputer }\end{array}$ & $\begin{array}{l}\text { Single chip minimum } \\
\text { system with LCD } \\
\text { controller }\end{array}$ \\
\hline $\begin{array}{l}\text { the use of } \\
\text { simulate devices }\end{array}$ & $\begin{array}{l}\text { The use of PAC-Designer 4.0 } \\
\text { and the circuit design based } \\
\text { on ispPAC20 }\end{array}$ & $\begin{array}{l}\text { Design of two-order } \\
\text { low-pass filter and } \\
\text { precision full-wave } \\
\text { rectifier circuit }\end{array}$ \\
\hline $\begin{array}{l}\text { the use of FPGA } \\
\text { and Verilog }\end{array}$ & $\begin{array}{l}\text { The use of Quartus and } \\
\text { design of hardware circuit } \\
\text { method by Verilog language }\end{array}$ & $\begin{array}{l}\text { Realization of } \\
\text { sequence detector } \\
\text { design with state } \\
\text { machine }\end{array}$ \\
\hline $\begin{array}{l}\text { Implementation } \\
\text { of DDS }\end{array}$ & $\begin{array}{l}\text { The basic principle of DDS } \\
\text { and the calculation and } \\
\text { transmission of periodic } \\
\text { signal parameters }\end{array}$ & $\begin{array}{l}\text { Realization of DDS } \\
\text { by AD9850 }\end{array}$ \\
\hline $\begin{array}{l}\text { Problems in the } \\
\text { realization of } \\
\text { electronic system }\end{array}$ & $\begin{array}{l}\text { The design methods of anti- } \\
\text { interference and Reliability } \\
\text { of Electronic System }\end{array}$ & $\begin{array}{l}\text { Design and assembly } \\
\text { of printed circuit } \\
\text { boards }\end{array}$ \\
\hline $\begin{array}{l}\text { Methods of debu- } \\
\text { gging electronic } \\
\text { systems }\end{array}$ & $\begin{array}{l}\text { Analog circuit, digital circuit } \\
\text { and single-chip system } \\
\text { debugging }\end{array}$ & $\begin{array}{l}\text { Design and } \\
\text { implementation of } \\
\text { their own system by } \\
\text { students }\end{array}$ \\
\hline
\end{tabular}

After the school teaching supervision attend a lecture of the single-chip processor programming competition held by Guangling College grade 2008 classes, they gave me a better evaluation for using such teaching methods.

\section{THE EFFORTS OF RESEARCH-ORIENTED INSTRUCTION SHOULD BE "VARY FROM PERSON TO PERSON"}

In the popularization of undergraduate education, students' demands for their diversity are understandable. Learning with the attitude of the study, after all, needs to consume more learning energy. Therefore, the efforts of research-oriented instruction should be "vary from person to person". I guide students to participate in the national college students electronic design competition, this process is just the best sample of research-oriented instruction in the electronic and information major undergraduate teaching. Students are willing to learn, and have a considerable degree of accumulation in disciplinary knowledge; meanwhile the time, place and equipment can also archive the best guarantee. The students deeply felt they got more experiments in these short periods of 2 months than the 3-years studying from book after they participated in the electronic competition, no matter what the results is. I also deeply appreciate the "vary from person to person" teaching methods, you can maximize the use of teaching resources, maximize the mobilization of the potential of students, maximize the satisfying the thirst for knowledge of students.
But unfortunately, in the undergraduate stage, the researchbased teaching method cannot carry out to every student because of a lot of conditional limits. Therefore, as a teacher, it is necessary to promoting research-oriented instruction in the usual daily teaching activities. In addition, the teachers also should take into account the needs of most students when teaching in the normal class, the requirements of the students cannot be one size fits all of these, of course. Since such method of work will take negative affect to the development of research-oriented instruction. Therefore, the author suggested that if college or professional permits the classes rearrangement, the classes can be divided into "fast" and "slow" class, "fast" class can implements more researchoriented instruction method, while "slow" class research uses these method less. Of course, such the way of "fast" "slow" class obviously increases the difficulty of teaching management; the fundamental solution is enrollment by mainly professional categories.

\section{CONCLUSION}

In short, students should vigorously be promoted by the study attitude in learning, teachers should actively carry out research-oriented instruction according to local conditions, research-oriented instruction should be reflected in the various aspects of teaching, important practice should be re-designed according to the thinking of research-oriented instruction, the establishment of teaching quality system and assessment should encourage the application of research-oriented instruction.

\section{REFERENCES}

[1] Zhang, Jia, Yuan, Jian, Han, Haozhang. Research on "TeachingLearning-Research" Blended Learning Innovation Model Among College Students Based on Internet. Journal of Computational and Theoretical Nanoscience, 2017.

[2] Chen L. Research and Practice on Advanced Mathematics' Classification and Stratification Teaching. Journal of Huaibei Normal University, 2016

[3] Wei Y. Teaching Research and Practice of Polymer Physics on Local Colleges. Guangdong Chemical Industry, 2016.

[4] Kong S C, Lai M, Wong T L. Toward a Framework of Studying Scholarship of Learning and Teaching in Higher Education in a Digital Technology Era. 2017.

[5] Englund C, Olofsson A D, Price L. Teaching with technology in higher education: understanding conceptual change and development in practice. Higher Education Research \& Development, 2016, 36:1-15.

[6] Song J, Center T E. Multidisciplinary Research on Higher Education from the Methodology Perspective. Modern Education Science, 2016. 